\title{
An International Comparison of Student Perceptions of Earnings Management Evidence of Effects of National Origin between Mexico and the United States ${ }^{1}$
}

\author{
Marshall A. Geiger* \\ Carmen Quirvan** \\ Alejandro Hazera***
}

\begin{abstract}
Manipulating reported earnings is a temptation faced by accountants and financial professionals around the world. Manipulating, or "managing," one's accounting earnings takes a variety of forms and includes not only the avoidance of prescribed accounting rules but also the practice of selectively choosing accounting estimates or timing operating decisions to move reported earnings toward a desired goal. Prior research reveals wide disagreement regarding the perceived ethical acceptability of this practice. This study investigates whether national origin influences perceptions of earnings management. Participants from the United States and Mexico evaluated thirteen vignettes describing various earnings management practices (Merchant and Rockness 1994). Analyses of the responses indicate considerable variation between students from these two countries, indicating culture does significantly impact how individuals perceive opportunities to manage reported financial information.
\end{abstract}

Key words: National origin; Manipulation of Financial Information; Culture; Ethics

Fecha de recepción: 11/01/2006

Fecha de aceptación: 11/05/2007

\footnotetext{
${ }^{1}$ Los autores agradecemos al Profesor Salvador Ruiz de Chávez por su apoyo en la recolección de información para el presente artículo.

*University of Richmond. Correo electrónico: mgeiger@richmond.edu

**University of Rhode Island. Correo electrónico: Quirvan@aol.com

***University of Rhode Island. Correo electrónico: Hazera@uriacc.uri.edu
} 
Marshall A. Geiger, Carmen Quirvan y Alejandro Hazera

\section{Resumen}

La manipulación de las utilidades reportadas es una tentación que enfrentan los contadores y profesionistas financieros en todo el mundo. Manipular o "administrar", las utilidades en la contabilidad toma diferentes formas e incluye no sólo el evitar los principios contables prescritos, sino también la práctica de escoger selectivamente estimaciones contables o retrasar decisiones operativas para informar de las utilidades conforme a un objetivo deseado. Investigación previa revela un amplio desacuerdo en la percepción y aceptación ética de esta práctica.

Este estudio investiga si el origen nacional influye en las percepciones éticas de la administración de las ganancias. Para ello, aplicamos un cuestionario de 13 preguntas a estudiantes de Contaduría de varias escuelas en México y los Estados Unidos; mismas que describen diversas prácticas en la administración de las utilidades ( Merchant y Rockness, 1994). El análisis de las respuestas de los encuestados indican una variación considerable entre estudiantes de ambos países, lo cual confirma que la cultura afecta significativamente en la forma cómo los individuos perciben las oportunidades para administrar la información financiera reportada.

Palabras clave: Origen Nacional, Manipulación de Información Financiera, Cultura, Ética.

\section{Introduction}

We are constantly bombarded with news of corporate wrongdoing. Hardly a month goes by without the announcement of someone, or some company, acting unethically in the context of financial reporting in the US (Jubak, 2002; Grimsley, 2002; U.S. House of Representatives, 2002) and abroad (Main, 2002). Accordingly, the evaluation of ethical behavior in financial reporting continues to be an important issue in business practice and in the preparation and evaluation of financial information. The examination of individual ethical perceptions is especially germane to the assessment of the overall ethical climate in our growing international business community. With the continued expansion of companies into the "global marketplace," it is increasingly important to examine the ethical perceptions of individuals from various cultures in an attempt to evaluate the ethical climate that may exist, and therefore the potential tendency for misleading financial information in this burgeoning financial marketplace.

The purpose of this study is to increase our understanding of current ethical perceptions regarding the financial reporting practice of "earnings management” (i.e., income 
smoothing, or manipulating income toward a desired goal), and whether those perceptions may be influenced by national culture. Specifically, we use an instrument previously developed by Merchant and Rockness (1994) to study Mexican and U.S. students' perceptions of the practice of earnings management. The instrument requires that students' provide perceptions of the "appropriateness" of earnings management under various scenarios.

The first part of the paper presents the theory and hypothesis development. The methodology and results are presented in the second and third sections. Future research and policy considerations are provided in the final section.

\section{Background and Hypotheses}

\section{Earnings Management}

Manipulating reported earnings is a very real temptation faced by all accountants and financial professionals (Healy, 1985; Jones, 1991; Guenther, 1994; Healy and Wahlen, 2000; Matsumoto, 2002; Moehrle, 2002). Manipulating, or “managing," one's earnings takes a variety of forms and includes the practice of selectively choosing accounting estimates or timing operating or investment decisions to move reported earnings either upwards or downwards toward a desired goal (Schipper, 1989; Merchant and Rockness, 1994; Healy and Wahlen, 2000). Prior research reveals considerable disagreement regarding the ethical acceptability of the practice of managing earnings (Bruns and Merchant, 1990; Merchant and Rockness, 1994; Fischer and Rosenzweig, 1995). While some individuals view these decisions as part of the typical set of financial reporting decisions and responsibilities, others view them as attempts to intentionally mislead the financial community (Mintz, 1997).

Earnings management is one of the most important ethical issues accountants face in everyday practice around the world (Armstrong, 1993). Investors and creditors in every nation depend on accountants to provide fair and reliable financial information regardless of national orientation. Financial statement users must be certain that companies report accurate information on which their decisions must be based. Companies that engage in earnings management may mislead the public regarding the true economic profitability and/or variability and sustainability of their operations. If truthful reporting does not exist, investors might be led to pay a premium to purchase the company's shares, and creditors might be led to lend money at a rate not commensurate with the underlying economic risk of the company. 
Although professional standards in all countries require accountants to present unbiased information (Choi et al., 1999), there are many ways to "manage” a company's reported accounting earnings (Schipper, 1989; Armstrong, 1993). A few examples of earnings management would include a company delaying the recognition of expenses or increasing its reported profits or assets to avoid violating existing debt covenants, or a group of executives intentionally delaying the signing of a profitable contract or underreporting company earnings in order to negotiate a favorable price in an anticipated management buyout offer. Company executives might also manage externally reported earnings in order to increase their bonus compensation, obtain loans on more favorable terms, increase or maintain the company's stock price, or report a smooth year-to-year revenues and earnings growth.

A large body of anecdotal and empirical evidence suggests that individuals or companies practice earnings management (Healy and Wahlen, 2000). Additionally, regulators in the US have also long expressed concern regarding the practice of earnings management (US House of Representatives, 1985, 1990). Former SEC (Securities and Exchange Commission) Chairman Arthur Levitt repeatedly voiced his concern that a growing number of corporations were eroding the quality of their financial reports by managing their reported earnings and presenting a skewed portrayal of the financial condition of their companies through the practice of earnings management (Levitt, 1998, 2000). Earnings management practices such as the practice of income smoothing are also well documented in countries outside of the US (Choi and Bavishi, 1983; Wallace et al., 1991). Consistent with these findings Ball et al. (2000) conclude that corporate earnings patterns differ across countries due to varied international institutional factors.

Building on these earlier works, this study investigates whether national culture may influence individual perceptions and judgments regarding the ethical acceptability of earnings management. An understanding of national differences in ethical judgments may be necessary to help interpret earlier research results and, from a practical perspective, becomes increasingly important as global trade and investment increase and as business people rely more heavily on financial statements prepared by individuals from foreign countries.

\section{National Origin and Perceptions of Earnings Management}

Ethical decision-making is deeply rooted in cultural values. Cultural norms concerning what is "right" and "wrong," "acceptable" and "unacceptable," "good" and "bad", and "important" and "unimportant" shape one’s beliefs regarding the world around us, including the business environment. These individual beliefs, then, gui- 
de perceptions of specific decisions, including the practice of earnings management (Fritzsche, 1988).

Several prior studies (e.g., Becker and Fritsche, 1987; Karnes et al., 1989: Shultz et al., 1993) suggest that ethical judgments in business are influenced by national origin. For example, Becker and Fritsche (1987) compared the ethical beliefs of marketing managers from the US, France, and Germany, and found significant differences related to nationality. Karnes et al. (1989) studied the ethical perceptions of accountants from the US and Taiwan. The US accountants were found to be more concerned about the legal consequences of their actions, while the Taiwanese accountants were more concerned about how their group would be affected. Cohen et al. (1996) found that auditor decision-making differed across countries. Roxas and Stoneback (1997) found that the ethical decision-making processes and the perceptions of accountants' responsibilities also differ across different cultures. Further, while seemingly similar, Whipple and Swords (1992) and Okleshen and Hoyt (1996) found that business students in the US have different ethical beliefs than business students in the United Kingdom and New Zealand. In a small sample study, Clikeman et al. (2001) found Asian students to view earnings management similarly to US students.

In this study, we extend these works by examining individuals from the US and Mexico regarding their ethical perceptions. Prior studies have examined broad differences in perceptions of general business ethical dilemmas across cultures. However, only recently have researchers begun to examine explicit perceptions toward the broad practice of earnings management. Most notable, Geiger et al. (2006) provide evidence that national origin affects perceptions of earnings management in countries in the English-speaking world and Europe. Our current article augments the research of Geiger et al. (2006) by examining differences in perceptions of earnings management between Mexico and the United States.

\section{Perceptions of Earnings Management in Mexico and the United States}

Merchant and Rockness (1994) report that judgments regarding the ethical acceptability of earnings management may depend on the type of the manipulation. Accordingly, we would expect that individuals from different countries would vary in their perceptions of earnings management on these different situational factors.

The factor addressed in our study is the type (TYPE) of earnings manipulation. Earnings can be manipulated either by altering the recording of existing transactions (accounting manipulations - ACC), or by timing operating activities near year-end to move revenues and expenses into desired periods (operating manipulations-OPER). Merchant and Rockness (1994) report that accountants judge accounting manipula- 
tions to be more serious ethical violations then operating manipulations. That is, the acceptability of breaking an accounting rule to accomplish earnings manipulation is less tolerable than engaging in operating manipulations.

Deeply rooted cultural differences between Mexico and the United States may affect those countries' perceptions of earnings management. With regard to the US, in his classic 1988 article, Gray argues that US business relations are based on arms' length transactions between independent third parties. ${ }^{2}$ Given these conflicting interests, transactions must be supported by detailed, legally enforceable contracts which outline the parties' consideration and obligations.

This adversarial concept of economic transaction is deeply rooted in the traditional "agency theory" concept of the corporate entity (Jensen and Meckling, 1976). Under this perspective, the corporate entity embodies a contract between shareholders and managers. In this agreement, corporate managers agree to administer the corporation's (i.e. the investors') resources and shareholders agree to compensate management (quite often on the basis of shareholder return). This structure is reflected in US stock markets, which are characterized by large numbers of publicly listed companies, relatively low concentration ratios in companies' ownership structures, and large numbers of "third party" investors with only an economic interest in the corporate entity (FASB, (Financial Accounting Standards Board), CICA (Canandian Institute of Certified Accountants), IMCP (Instituto Mexicano de Contadores Públicos), 1995).

In this legalistic context, financial reports are largely seen as a method by which management communicates its representations regarding its contractual obligations to the independent shareholders (i.e. owners) of the corporation. Accordingly, financial reports are constructed on the basis of legalistic, detailed accounting rules (i.e. the standards of the Financial Accounting Standards Board) which (attempt to) address aspects of even complex transactions. As a result, accountants and auditors frequently take a "rules-oriented" approach which mainly emphasizes financial statement compliance with GAAP.

In contrast to this strong legal orientation, Gray [1988] argues that business transactions in Latin American societies are based more on the social aspects of relations, such as family and friendship ties. This orientation may be reflected in traditional Mexican businesses, which are based on more a "closely-held" ownership structure. These structures may also be reflected in the Mexican Stock Exchange (MSE), which

\footnotetext{
${ }^{2}$ Gray's (1988) article was the first to relate Hostede's dimensions of culture to accounting standard- setting. A more recent critique of this work is found in Baskerville (2003). 
is characterized by relatively few publicly-listed companies, a high concentration of shares in the hands of a few individuals, a relatively few "independent" shareholders (FASB, CICA, IMCP, 1995).

In a reflection of these characteristics, there is relatively less demand for financial statements as a method for verifying management's obligation to third party investors. Also, Mexican GAAP tend to be less detail-oriented than US GAAP.

\section{Hypotheses}

Based on the preceding discussion, we would anticipate that national culture impacts individual perceptions regarding earnings management. Specifically, we would expect that individuals from different countries would differ across their perceptions of earnings management. Therefore, our set of hypotheses is:

$\mathrm{H}_{1}$ : $\quad$ Perceptions of earnings manipulations will differ across the two countries.

$\mathrm{H}_{2}$ : $\quad$ Perceptions of accounting rules-based earnings manipulations (ACC) will differ across the two countries.

$\mathrm{H}_{3}$ : $\quad$ Perceptions of operating decisions to manipulate based earnings (OPER) will differ across the two countries.

$\mathrm{H}_{4}$ : $\quad$ Perceptions of the differences between accounting (ACC) and operating (OPER) manipulations (TYPE) will differ across the two countries.

\section{Methodology}

\section{Earnings Management Questionnaire}

The participants answered a questionnaire that asked them to evaluate the ethical acceptability of 13 earnings management activities. The scenarios were originally developed by Bruns and Merchant (1990) and subsequently used by Merchant and Rockness (1994) and Fischer and Rosenzweig (1995) to study perceptions of the ethics of earnings management. The scenarios address relatively simplistic practices such as delaying discretionary expenses to increase earnings and the intentional manipulation of inventory reserves. Subjects responded to each scenario using a 5-point scale ranging from 1 for "ethical practice" to 5 for "totally unethical." Thus, higher scores indicate that the action proposed is perceived as more unethical than actions represented by lower scores. (A copy of the questionnaire is included in the Appendix.) 
The questionnaire also includes activities that vary the type (ACC, OPER, and TYPE-accounting versus operating manipulation) of the manipulation. Merchant and Rockness (1994) report that professional accountants' judgments of the ethical acceptability of earnings management are influenced by these factors.

It should also be noted that in our study we analyze more than one ethical dilemma regarding the broad earnings management issue. The use of multiple situations has been argued to better capture an individual's ethical orientation than the use of a single, or just a few, ethical scenarios (Randall and Gibson, 1990).

\section{Subjects}

The participants in this study were business students from one public and one private university in the US and one private and four public universities in Mexico. ${ }^{3}$ Participation was voluntary and the responses to the questionnaire were anonymous. In order to ensure that the students understood the nature of the accounting scenarios, participation was limited to upper-level students and data was collected toward the end of the courses. After eliminating unusable responses, we obtained complete data for 366 US and 202 Mexican students.

\section{Results and Discussion}

Table 1 indicates the mean response to each of the 13 earnings management scenarios by country and in the aggregate. Mean responses varied considerably across the scenarios. In order to better assess differences between the two countries regarding responses to the individual questions, and the average overall response, we ran unbalanced ANCOVAs that also control for age of the student and whether they were an accounting major or not in the ANCOVA models as co-variates. ${ }^{4}$ The p-values reported in the last column of Table 1 are for the independent country variable in the type III sum of squares analyses for each of these separate ANCOVA models.

\footnotetext{
${ }^{3}$ In order to get a better cross-section of the perceptions of the individuals from both countries, we used multiple sites in the same country to collect our data. In that way, we believe that we present a better representation of the general perceptions towards these issues within each country than if we collected data from only one or two groups of participants. Accordingly, all country locations have been combined for analysis. The US universities were the University of Richmond and the University of Rhode Island. The Mexican universities included Universidad Autónoma de Aguascalientes, Universidad de Monterrey, Universidad del Estado de México, Universidad de San Luis Potosí, Universidad de Tlaxcala.

${ }^{4}$ Separate t-tests find no significant difference between the Mexico and US students in terms of average age (21.92 vs. 21.74 years, respectively); however, more students from Mexico declared accounting as a major (93.2\%) than in the US (80.8\%).
} 
An examination of the results in Table 1 indicates that, overall, the US participants had slightly higher (mean of 2.673) more negative perceptions of the 13 earnings management cases presented than their Mexican peers (mean of 2.541; difference is significant at $\mathrm{p}<.0226$ ). Further, on 10 of the 13 individual questions the US and Mexican students differed significantly $(\mathrm{p}<.05)$ in their aggregate perception toward the earnings management issue presented. Of these 10 significantly different responses to individual scenarios, US participants viewed seven as more unethical (had high average scores) than their Mexican peers. A binomial test rejects $(\mathrm{p}<.01)$ this overall pattern of 10 out of 13 average response differences as a chance occurrence. Thus, we find that US and Mexican students differ significantly in their perceptions of the acceptability of earnings management practices, with the participants from Mexico generally more in favor of the practice than their US counterparts.

\section{Situational Factors that Influenced Judgments}

Table 1 (in page 68) also reports the influence of situational factors on the ethical judgments for the participants in our study. As previously discussed, earnings can be managed either by altering the recording of existing transactions (accounting manipulation) or by timing year-end transactions to move revenues and expenses into the desired reporting period (operating manipulation). The students' mean response to the seven accounting manipulation scenarios (ACC) is 2.998. The students' mean response to the six operating manipulation scenarios (OPER) is 2.192. The overall difference of 0.805 between ACC and OPER, reflecting the difference in type of manipulation (TYPE) is significant at $\mathrm{p}<.01$. Consistent with their practitioner counterparts (Merchant and Rockness, 1994), accounting students find violations of accounting rules more ethically troubling than operating manipulations of income.

Examination of Table 1 also indicates that while participants from both countries viewed ACC violations more significant than OPER violations, US students viewed the ACC cases, in general, significantly less favorable than their Mexican peers. However, both groups perceived the OPER case manipulations more similarly $(\mathrm{p}=.0912)$. Accordingly, the TYPE results are also significant, largely due to the country differences in the ACC cases. In sum, the US students appeared to be more concerned with the earnings manipulations that would violate established accounting rules (ACC) than their Mexican peers, and both groups had similar perceptions of operating manipulations (OPER).

\section{Conclusions}

Earnings management is one of the most important practical ethical issues faced by accountants. Accountants are responsible for publishing fair and reliable financial 
statements, but many incentives exist for companies to try to move their reported earnings toward a desired goal. Prior research reveals wide disagreement among accountants regarding the ethical acceptability of earnings management (Bruns and Merchant, 1990; Merchant and Rockness, 1994).

The key finding of this study is that while it is largely acknowledged that the US and Mexico have very different national cultures, these differences also are evident in student perceptions regarding the ethical acceptability of the practice of earning management. The results of our study provide evidence that while students from both countries viewed operational earnings management as unethical, U.S. students viewed non-compliance with GAAP more seriously than Mexican students. This finding supports the legalistic "rules"-oriented approach to financial reporting that has been adopted in the United States.

Supporters of this perspective may argue that such strict adherence to detailed rules helps prevent accounting earnings manipulation. However, as US accountants learned in the recent US fraud cases such as Enron (See Moncarz, et al., 2006), simple following of the rules may not prevent earnings management when the rules are incomplete or when the rules do not correspond with ethical or economic substance of a transaction. Thus, further research is needed regarding international perceptions of earnings management as well as their implications to investors.

\section{Appendix}

\section{Instructions:}

The following questions reflect everyday ethical choices. Please evaluate the practices as they apply to a major division (annual revenues of, say, $\$ 100$ million) of a billion-dollar public company. Use the following scale to indicate how you judge their acceptability.

1. Ethical practice.

2. Questionable practice. I would not say anything to the manager, but it makes me uncomfortable.

3. Minor infraction. The manager should be warned not to do it again.

4. Serious infraction. The manager should be severely reprimanded.

5. Totally unethical. The manager should be fired. 


\section{Questions:}

1. The division's headquarters building was scheduled to be painted in 2003. But since profit performance was way ahead of budget in 2002, the division general manager (GM) decided to have the work done in 2002. Amount: \$150,000.

2. The GM ordered his employees to defer all discretionary expenditures (e.g., travel, advertising, hiring, maintenance) into the next accounting period, so his division could make its budgeted profit targets. Expected amount of deferrals: $\$ 150,000$.

a. The expenses were postponed from February and March until April in order to make the first quarter target.

b. The expenses were postponed from November and December until January in order to make the annual target.

3. On December 15, a clerk ordered $\$ 3,000$ of office supplies, and the supplies were delivered on December 29. This order was a mistake because the GM had ordered that no discretionary expenses be incurred for the remainder of the fiscal year, and the supplies were not urgently needed. The company's accounting policy manual states that office supplies are to be recorded as an expense when delivered. The GM learned what had happened, and to correct the mistake, he asked the accounting department not to record the invoice until February.

4. In September, the GM realized the division would need strong performance in the fourth quarter to reach its budget targets.

a. He decided to implement a sales program offering liberal payment terms to pull some sales that would normally occur next year into the current year; customers accepting delivery in the fourth quarter would not have to pay the invoice for 120 days.

b. He ordered manufacturing to work overtime in December so that everything possible could be shipped by the end of the year.

c. He sold some excess assets and realized profit of $\$ 40,000$.

5. At the beginning of December 2003, the GM realized the division would exceed its budgeted profit targets for the year. 
a. He ordered his controller to prepay some expenses (e.g., hotel rooms, exhibit expense) for a major trade show to be held in March 2004 and to book them as 2003 expenses. Amount: \$60,000.

b. He ordered his controller to develop the rationale for increasing the reserve for inventory obsolescence. By taking a pessimistic view of future market prospects, the controller was able to identify $\$ 700,000$ worth of finished goods that conservative accounting would say should be fully reserved (i.e., written off), even though the GM was fairly confident the inventory would still be sold at a later date at close to full price.

6. The next year, the division sold $70 \%$ of the written-off inventory, and a customer had indicated some interest in buying the rest of that inventory the following year. The GM ordered his controller to prepare the rationale for reducing the reserve for obsolescence by $\$ 210,000$ (i.e., writing up the previously written-off goods to full cost). The GM's motivation for recapturing the profit was:

a. To be able to continue working on some important product development projects that might have been delayed due to budget constraints.

b. To make budgeted profit targets.

7. In November 2004, the division was straining to meet budget. The GM called the engagement partner of a consulting firm that was doing some work for the division and asked that the firm not send an invoice until next year. The partner agreed. Estimated work done but not invoiced:
a. $\$ 30,000$
b. $\$ 500,000$

\section{Bibliography}

Armstrong, M.B. (1993). Ethics and professionalism for CPAs. Cincinnati, OH: Southwestern.

Ball, R., S.P. Kothari, and A. Robi (2000). The effect of international institutional factors on properties of accounting earnings. Journal of Accounting And Economics, vol. 29, núm. 1 (pp. 1-51).

Baskerville, R.F. (2003). Hofstede never studied culture. Accounting, Organizations, and Society, vol. 28 (pp. 1-14). 
BeCKeR, H. and D.J. Fritsche (1987). A Comparison of the Ethical Behavior of American, French, and German Managers. Columbia Journal of World Business, vol. 22 (87-95).

Beltramini, R, R. Peterson and G. Kozmetsky (1984). Concerns of College Students Regarding Business Ethics. Journal of Business Ethics, vol. 3 (195-200).

Bruns Jr., W.J and K.A. Merchant (1990). The Dangerous Morality of Managing Earnings. Management Accounting, august (pp. 22-25).

Camp, A.R. (1999). Democracy through Mexican lenses. The Washington Quartely, vol.22, núm. 3 (229-242).

Chor, F.D. and V.B. Bavishi (1983). International Accounting Standards: Issues Needing Attention. Journal of Accountan, vol. 155, núm. 3 (62-68).

C. A. Frost and G. K. Meek (1999). International Accounting ( $3^{\text {rd }}$ ed.). New York: Prentice-Hall, Upper Saddle River.

Clikeman, P. M., M. A. Geiger and B. T. O’Connell (2001). Student Perceptions of

Earnings Management: The Effects of National Origin and Gender. Teaching Business Ethics, vol. 5 (389-410).

Cohen, J.R., L.W. Pant and D.J. Sharp (1996). A Methodological Note on Cross Cultural Accounting Ethics Research. The International Journal of Accounting, vol. 31 (55-66).

Davis, J. F. and R. Welton (1991). Professional Ethics: Business Students "Perception”. Journal of Business Ethics, vol. 10, núm. 6 (451-463).

Fischer, M. and K. Rosenzweig (1995). Attitudes of Students and Accounting Practitioners Concerning the Ethical Acceptability of Earnings Management. Journal of Business Ethics, vol. 14 (433-444).

Financial Accounting Standards Board, Canadian Institute of Chartered Accountants and Instituto Mexicano de Contadores Públicos. 1995. Financial Reporting in North America.

Fritzsche, D. J. (1988). An Examination of Marketing Ethics: Role of the Decision Maker, Consequences of the Decision, Management Position, and Sex of the Respondent. Journal of Macromarketing, vol. 8 (pág. 29-39).

Fulmer, W. E. and B. R. CARgiLe (1987). Ethical Perceptions of Accounting Students: Does Exposure to a Code of Professional Ethics Help? Issues in Accounting Education, vol. 2, núm. 2 (207-219). 
Geiger, M.A., B.T. O’Connell, P.M. Clikeman, E. OchoA, K. Witkowski and I. BaSIOUDIS (2006). Perception of Earnings Management: The Effects of National Culture. Advances in International Accounting, núm. 19 (175-199).

Giacomino, D. E. (1992). Ethical Perceptions of Accounting Majors and Other Business Majors: An Empirical Study. Accounting Educators' Journal, núm. 5 (1-26).

GraY, S.J. (1988). Towards a theory of cultural influences on the development of accounting standards internationally. Abacus, núm. 24 (1-15).

GrimsLey, K.D. (2002, february 19). Auditors pushed into revolving door. The Washington Post (A01).

Jensen M. and W. Meckuing (1976). Theory of the firm: Managerial behaviour, agency costs and ownership structure. Journal of Financial Economics, vol. 3 (pp. 305-360).

Jubak, J. (2002). Companies whose boards need a scare. April 3, 2002. MSN Money Markets Personal Finance Editor at http://www.thestreet.com/funds/ jubak/10015517.html

Healy, P. (1985). The Effects of Bonus Schemes on Accounting Decisions. Journal of Accounting and Economics 7 (pp. 85-107).

Healy, P. and J. M. Wahlen (2000). A Review of the Earnings Management Literature and its Implications for Standard Setting. Accounting Horizons, núm. 13 (pp. 365-383).

Hofstede, G. L. (1980). Culture's Consequences. Newbury Pary, CA: Sage Publications.

Karnes, A., J. Sterner, R. Welker and F. Wu (1989). A Bicultural Study of Independent Auditors' Perceptions of Unethical Business Practices. The International Journal of Accounting, núm. 24 (29-41).

LevitT Jr., A. (1998). The Numbers Game. The CPA Journal, december (15-19).

$$
\text { York }
$$

(2000). Renewing the Covenant with Investors. Remarks before the New University Center for Law and Business, May 10.

MaIn, A. (2002). HIH Cut Corners From Start: Inquiry. The Australian Financial Review, august, núem. 18 (p. 1).

Matsumoto, D. A. (2002). Management's incentives to avoid negative earnings surprises. Accounting Review, july, vol. 77, núm. 3 (483-514). 
Merchant, K.A. and J. Rockness (1994). The Ethics of Managing Earnings: An Empirical Investigation. Journal of Accounting and Public Policy, núm. 13 (79-94).

Mintz, S. (1997). Cases in accounting ethics and professionalism (3 ${ }^{\text {rd }}$ edition), New York: McGraw-Hill.

MoenrLe, S. R. (2002). Do firms use restructuring charge reversals to meet earnings targets? Accounting Review, april, vol. 77, núm. 2 (pp. 397-414).

Moncarz, E.S., R. Moncarz, R., Cabello, A. and Moncarz, B. (2006), The Rise and Collapse of Enron: Financial Innovation, Errors and Lessons. Contaduría y Administración. Jan.-April, 17-37.

Roxas, M. L., and J. Y. Stoneback (1997). An Investigation of the Ethical DecisionMaking Process Across Varying Cultures. The International Journal of Accounting 32: 503-535.

Schipper, K. (1989). Commentary on earnings management. Accounting Horizons, vol. 3, núm. 4, december (pp. 91-102).

US House of Representatives (1985). Hearings before the subcommittee on oversight and investigations of the committee on energy and commerce, february 20, núm. 99-17.

(1990). Hearings before the subcommittee on telecommunications and finance of the committee on energy and commerce, august 2, núm. 101-196.

(2002a). H.R.3818. Comprehensive Investor Protection Act of 2002. U.S. House of Representatives. Washington, DC: Government Printing Office.

. (2002b). Sarbanes-Oxley Act of 2002. $107^{\text {th }}$ Congress, $2^{\text {nd }}$ Session.

U.S. Senate (2002, february 12 and 26). Oversight Hearing on Accounting and Investor Protection Issues. Raised by Enron and Other Public Companies. US Senate Committee on Banking, Housing and Urban Affairs.

Wallace, R., S. Olusegun and H. Gernon (1991). Frameworks for International Comparative Financial Accounting. Journal of Accounting Literature, núm. 10 (pp. 209-264).

Whipple, T. and D.F. Swords (1992). Business Ethics Judgments: A Cross Cultural Comparison. Journal of Business Ethics, núm. 11, (pp. 671-678). 
Marshall A. Geiger, Carmen Quirvan y Alejandro Hazera

Table 1

Mean Responses to Earnings Management Scenarios

\begin{tabular}{|l|l|l|l|c|}
\hline \multicolumn{1}{|c|}{ Scenario } & $\begin{array}{l}\text { All } \\
\text { participants } \\
(\mathrm{N}=568)\end{array}$ & $\begin{array}{l}\text { Mexico } \\
(\mathrm{N}=202)\end{array}$ & $\begin{array}{l}\text { United } \\
\text { States } \\
(\mathrm{N}=366)\end{array}$ & $\begin{array}{l}\text { Differences } \\
\text { between } \\
\text { Countries* } \\
\text { (p-values) }\end{array}$ \\
\hline 1. Paint building early & 1.289 & 1.559 & 1.139 & .0001 \\
\hline 2a. Defer expenditures for quarter & 2.771 & 2.569 & 2.883 & .0010 \\
\hline 2b. Defer expenditures for year & 3.312 & 2.980 & 3.495 & .0001 \\
\hline 3. Record supplies next year & 3.234 & 3.223 & 3.240 & .8116 \\
\hline 4a. End of year sales program & 2.093 & 2.168 & 2.052 & .1136 \\
\hline 4b. Overtime in December & 1.891 & 2.153 & 1.746 & .0001 \\
\hline 4c. Sell unused assets & 1.799 & 1.970 & 1.705 & .0031 \\
\hline 5a. Prepay \$60K travel expenses & 2.678 & 2.713 & 2.658 & .2539 \\
\hline 5b. Writedown \$700K inventory & 3.129 & 2.926 & 3.242 & .0024 \\
\hline 6a. Writeup inventory-product development & 2.540 & 2.317 & 2.664 & .0003 \\
\hline 6b. Writeup inventory-meet budget & 2.942 & 2.391 & 3.246 & .0001 \\
\hline 7a. Delay recording \$30K invoice & 2.776 & 2.634 & 2.855 & .0205 \\
\hline 7b. Delay recording \$500K invoice & 3.685 & 3.431 & 3.825 & .0001 \\
\hline \multicolumn{1}{|c|}{ Average } & 2.626 & 2.541 & 2.673 & .0226 \\
\hline ACC (3+ 5a + 5b +6a + 6b + 7a + 7b)/7 & 2.998 & 2.805 & 3.104 & .0001 \\
\hline OPER (1+2a + 2b + 4a + 4b + 4c)/6 & 2.192 & 2.233 & 2.170 & .0912 \\
\hline TYPE ACC - OPER & 0.805 & 0.571 & 0.935 & .0001 \\
\hline
\end{tabular}

${ }^{*}$ p-values are from the type III sum of squares for the country variable from each ANCOVA model using accounting major (0/1) and age as co-variates.

ACC $=$ Accounting manipulations

OPER = Operating manipulations

TYPE = Accounting manipulations less operating manipulations 